\title{
Making Iowa Safe for Differences: Barnstorming Iowa on Behalf of Religious Tolerance, 1936-1943
}

\author{
BiLl R. DOUGLAS
}

A PRIEST, a minister, and a rabbi walk into a high school gymnasium. Is this the beginning of a bad joke? Cultural insensitivity? An attack on religious authority? Three Des Moines clergy known as the Des Moines Brotherhood Trio or the Goodwill Team exploited that discomfort by doing just that-walking into high school gymnasiums (and other settings) throughout lowa during the late 1930s and early 1940s and confronting potential prejudice with doses of humor and religion, civility and civil religion.

In 1937 in a somewhat different setting, at the celebration of the tenth anniversary of the founding of the State University of Iowa's School of Religion, Stoddard Lane, the Protestant minister of the trio, expounded on the similarities of Judaism, Catholicism, and Protestantism, the three religious entities represented in the school. Then, in seeming contradiction, he called for "making America safe for differences." 1 It was that tension-between civility and curiosity, between neighborliness and religious loyalty, between recitations of similarities and celebrations of differences - that made the Des Moines Brotherhood Trio's balancing act so engaging.

The typical scenario for the Brotherhood Trio played out as a skit set in the office of Willard Johnson, who organized the gatherings and acted as straight man for the clergy. Rabbi Eugene

1. Iowa City Press-Citizen, 11/23/1937. "Making America safe for differences" was the 1937 slogan for the National Conference of Christians and Jews.

THE ANNALS OF IOWA 75 (Summer 2016). (C) State Historical Society of Iowa, 2016. 
Mannheimer, Father Robert Walsh, and Reverend Stoddard Lane all played to an audience that was eager to be praised for its own tolerance and was naturally curious about how others worshiped and lived - whether it was the Catholics across town or Jews they may never have encountered. Taking the audience into their confidence as they strategized how to persuade Iowans to support diversity, the Brotherhood Trio's self-deprecating humor and mutual teasing played well among small-town audiences who navigated everyday life in the same ways. The trio's repertoire resonated with American traditions of religious tolerance, Iowa settlement patterns, and the community ethic of cooperation.

The winding American path toward acceptance of religious pluralism was plotted by colonial dissidents and affirmed by the First Amendment, but was contested nonetheless. ${ }^{2}$ Kevin Schultz's 2011 book Tri-Faith America identified a religious tolerance project promoted in the 1930s by the National Conference of Christians and Jews - and, in passing, its Des Moines incarnation - as the foreshadowing of a tri-faith, "Protestant-Catholic-Jew" dominance in mid-century America. ${ }^{3}$

The purpose of this article, in addition to providing a local perspective on that national project, is to trace the roots of Iowa pluralism in the sometimes contentious, sometimes cooperative, 1910s and 1920s. Des Moines Bishop Gerald Bergan credited the Goodwill Trio with fundamentally changing the culture of the state. Their publicity agent, Willard Johnson (who would later become a prominent staff member of the National Conference of Christians and Jews) dubbed them the Corn-Belt Crusaders. ${ }^{4}$ (They did not refer to themselves that way - with a pacifist and a Jew in the mix, it's clear why not.) What the Des Moines Brotherhood Trio actually did was subtler: they exploited the religious

2. Two standard accounts are William R. Hutchison, Religious Pluralism in America: The Contentious History of a Founding Ideal (New Haven, CT, 2003); and Charles H. Lippy, Pluralism Comes of Age: American Religious Culture in the Twentieth Century (Armonk, NY, 2000). I thank Dr. Lippy for his helpful comments as responder to an earlier version of this paper, presented at the Spring 2015 conference of the American Society of Church History.

3. Kevin Schultz, Tri-Faith America: How Catholics and Jews Held Post-War America to Its Protestant Promise (New York, 2011); Jonathan D. Sarna, American Judaism: A History (New Haven, CT, 2004), 266-67.

4. James E. Pitt, Adventures in Brotherhood (New York, 1955), 58, 62. 
diversity of the state to suggest that, in the context of a modern world that could be either monolithic or diverse, diversity was a good idea.

TWO OF THE THREE members of the Brotherhood Trio had known each other for several years before joining more formally in this effort to promote religious tolerance. Reverend Stoddard Lane was minister of the most prominent Protestant congregation in the state, Des Moines's Plymouth Congregational Church. He had established a close friendship with Rabbi Eugene Mannheimer of Temple B'nai Jeshurun. Father Robert Walsh of Dowling Academy was appointed by Bishop Bergan of the Diocese of Des Moines to join the group. Not all Roman Catholic dioceses were willing to cooperate in interfaith efforts in the 1930s, but the Des Moines Round Table, the local affiliate of the National Conference of Christians and Jews (NCCJ), sponsored the first trio appearances in 1936; by 1938, the newly created regional office of the NCCJ began organizing events across Iowa. While the trio played themselves as representatives of their respective traditions, their own backgrounds also shaped their cooperative venture.

The easiest and arguably the best way to examine interfaith efforts in Des Moines after 1905 is to follow the career of Rabbi Eugene Mannheimer. Born in Rochester, New York, he grew up in Cincinnati, Ohio, the hotbed of Reform Judaism. Mannheimer was a towering figure in Des Moines's religious ecosystem in the first half of the twentieth century. Founder of the Jewish Federation of Des Moines, civic activist, bold promoter of progressive religion in Reform Judaism, and a representative of the last generation of non-Zionist rabbis to lead prominent congregations, he left behind a 17 -volume unpublished memoir. ${ }^{5}$ Mannheimer is

5. Jewish Federation of Greater Des Moines, 100th Anniversary, 1914-2004: Celebrating a Century of Benevolence [Des Moines, 2014], 13; Michael J. Bell, " 'True Israelites of America': The Story of the Jews in Iowa," Annals of Iowa 53 (1994), 111-15; Eugene Mannheimer, "Reminiscences of My Three Score Years and Ten," typescript, State Historical Society of Iowa, Des Moines. As invaluable as Mannheimer's memoir is - for example, Frank Rosenthal's Jews of Des Moines (1957) is almost entirely based on it - it should be used with care; at times, points made in later volumes contradict things in earlier volumes. On Mannheimer's non-Zionism, rooted deeply in his American Judaism - and his personal lack of contact with anti-Semitism - he states, "The first time . . . that I ever heard any speaker suggest that the Jew is not, never has been, and never can be 'at home' 
still remembered by congregation members today for his edgy decisions, such as holding services on Sunday mornings. ${ }^{6}$

Mannheimer was also present at the creation of the School of Religion at the State University of Iowa in Iowa City. ${ }^{7}$ That project was unique in its reliance on the state's religious communities for much of its support. Eventually the hybrid decision-making process blending academic and denominational representation would become an administrative headache. Yet at the outset the breadth of the endeavor was impressive. In retrospect, Willard Lampe, the longtime director of the school, later recalled that many of the participants in the first planning meeting at the Old Capitol in Iowa City, on May 12, 1925, "had never met each other before, and none of them had ever been in that kind of meeting. But it was ... a deeply moving occasion." 8 Mannheimer confirmed the momentousness of the occasion, after citing university president Walter Jessup's extravagant claim: "This is the broadest piece of co-operative work ever undertaken along the lines of religion at a State University." Mannheimer rejoined, "Far more than that, it is,

in America, was in Des Moines, from the lips of a Zionist speaker, October 13, 1911." Mannheimer, "Reminiscences," 1:5. For a current exposition of that view, see Alan Wolfe, At Home in Exile: Why Diaspora Is Good for the Jews (Boston, 2014). Mannheimer was also troubled by American expansionism; see Des Moines Register, 2/21/1947.

6. Conversation with Temple member Elyse Weiss, Des Moines, 2/28/2015. When Clarence Darrow came to Des Moines in 1928, fresh from his confrontation with William Jennings Bryan and the latter's pyrrhic victory in the Scopes Trial, it was Mannheimer who debated him, on the topic "Is Man a Machine?" - and arguably out-agnosticized him; when Darrow asked rhetorically, "If man is not a machine, what is he?" the rabbi replied, "Nobody knows; but he is not a machine." Mannheimer, "Reminiscences, 2:258; Des Moines Register, 11/15/1928; Des Moines Tribune-Capital, 11/15/1928; Schultz, Tri-Faith America, 29.

7. For a fascinating look at earlier attempts at interfaith education at the State University of Iowa, see M. Thomas Starkes, "Glimpses of Greatness: O. D. Foster" (M.A. thesis, State University of Iowa, 1967), 69-78.

8. M. Willard Lampe, The Story of an Idea: The History of the School of Religion of the University of Iowa (Iowa City, 1951), 4. Marcus Bach, a professor at the School of Religion and popularizer of American religious studies, also wrote about the school's origins in Of Faith and Learning: The Story of the School of Religion at the State University of Iowa (Iowa City, 1952). On the school's structural problems, see The School of Religion at the University of Iowa: The First Seventy Years (Iowa City, 1997), 11, and folder 32, box 5, William Francis Riley Papers, Special Collections, University of Iowa Libraries, Iowa City, Iowa. 


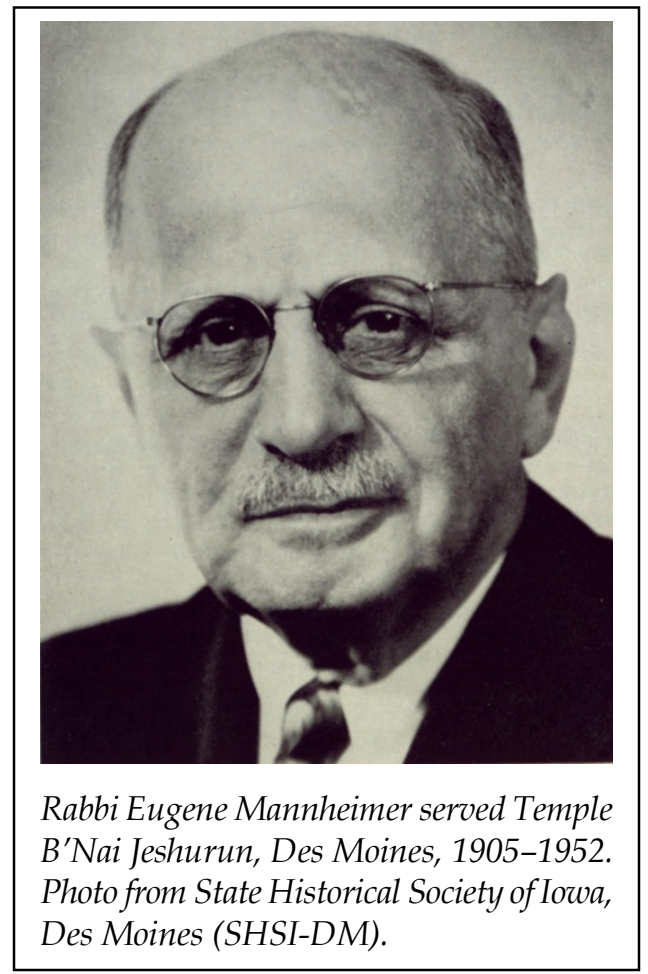

perhaps, the biggest and broadest piece of cooperative work ever undertaken by Protestants, Catholics, and Jews." 9

After that promising beginning, Mannheimer heard nothing of the project for over a year, so he chalked it up to unrealistic expectations. But the university had not been negligent; in August 1926 it announced that it had secured startup funding for its School of Religion from John D. Rockefeller, and planning began in earnest. Mannheimer served on the governing board for several decades, with most of his time spent fundraising in the Iowa Jewish community and supervising the Jewish faculty member, who was also supposed to provide extracurricular support for

9. Mannheimer, "Reminiscences," 2:259, 283-88; folder 1, box 26, Ora Delmar Foster Papers, Special Collections, University of Iowa Libraries, Iowa City, Iowa. Interfaith understanding obviously was not complete, for records indicate that Rabbi Mannheimer was selected by his "church" to be an elector for the school's board of trustees. 


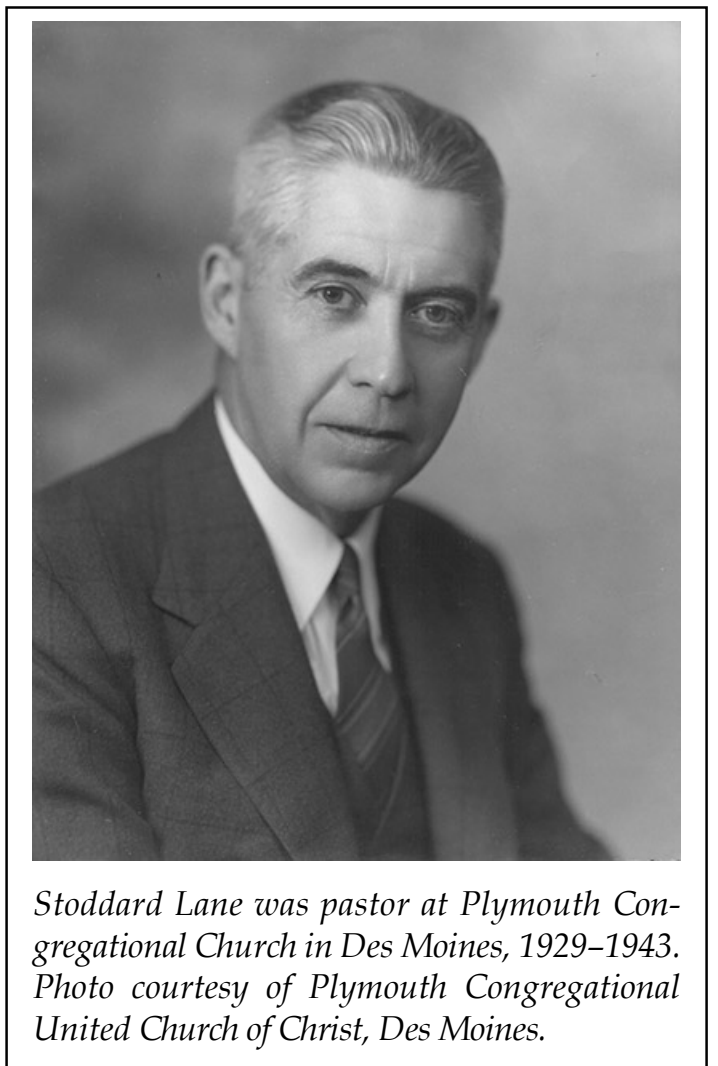

Jewish students. Professor O. D. Foster, who had the original idea for the school, credited Mannheimer with a "humorous remark" at an early meeting that saved the school from dying even before it was born. ${ }^{10}$

The second member of the trio, Stoddard Lane, arrived in Des Moines in 1929 as pastor of Plymouth Congregational Church, the most prestigious Protestant pulpit in the state. ${ }^{11}$ He soon struck up a close friendship with Mannheimer. ${ }^{12}$ Lane's New England

10. Unfortunately, Mannheimer, in his memoir, admitted that he could not remember what the quip was that saved the day. Mannheimer, "Reminiscences," 2:296, 3:324-31, 335-64, 370.

11. Des Moines Tribune, 12/1/1956, 6/19/1982.

12. A similar friendship is documented in Carl Hermann Voss, Rabbi and Minister: The Friendship of Stephen S. Wise and John Haynes Holmes (Buffalo, NY, 1980). 
background - he was born in Unionville, Connecticut, in 1887, and was a graduate of Hartford Seminary in 1913 - gave him cachet in Iowa Congregationalist circles. It is likely that his pacifism was a consequence of his service as a sergeant in the U.S. Ambulance Corps in France during World War I. "I have seen men, women, and children strangling to death in poison gas," he told college students in 1932. In his 14 years in Des Moines before his untimely death in 1943, Lane emulated his friend Eugene Mannheimer in steering a progressive course for his ministry. He chaired the Des Moines Ministerial Alliance and was a trustee of Grinnell College. His pacifism continued unswayed after the attack on Pearl Harbor. He advocated on behalf of a colleague who had been fired by the Newton Congregational Church for taking a pro-union stand during the Maytag sit-down strike in Newton, Iowa, in 1938. His two extant sermons exude wisdom and gentleness. ${ }^{13}$

The least prominent member of the Des Moines Brotherhood Trio was Father Robert A. Walsh. An English instructor at the Dowling Academy and editor of the diocesan newspaper, the Des Moines Messenger (now the Catholic Mirror), in 1940 and 1941, Walsh, originally from Philadelphia, had attended Columbia College (now Loras) in Dubuque, was a graduate of St. Bonaventure College in western New York, and was ordained in 1926. ${ }^{14}$ Mannheimer credited him with being the best storyteller in the group..$^{15}$ There is in the statement a hint, not of condescension, but of trying to bridge a gap between the prominent and the obscure.

13. Stoddard Lane, 1887-1943 [Des Moines, 1943]; In Memoriam: Stoddard Lane (Grinnell, 1943); Stoddard Lane, "The Challenge to Disarmament," Grinnell College] Tanager 8, no. 2 (November 1932), 37; Iowa Fellowship News, February 1942; Stoddard Lane et al., "Labor Troubles and the Local Church," Social Action, 1/15/1939; Stoddard Lane, "It's Hard to Believe in Christmas!" 12/22/1940, typescript, Des Moines Public Library Central Library, Des Moines; "There Are Things That Abide Always," 8/30/1942, in Stoddard Lane [no pagination]; Grinnell [College] Scarlet and Black, 1/13/1937.

14. St. Bonaventure College and Seminary, Alumni Directory, 1859-1941; The Aquin (student monthly for Des Moines Catholic College, ca. 1931), copy in Dowling Catholic High School files, West Des Moines. One of Walsh's radio addresses is extant: "Making America Safe for Differences," in Robert A. Walsh personnel file, Archives of the Diocese of Des Moines and in Des Moines Messenger, 1/27/1939.

15. Pitt, Adventures in Brotherhood, 59. 


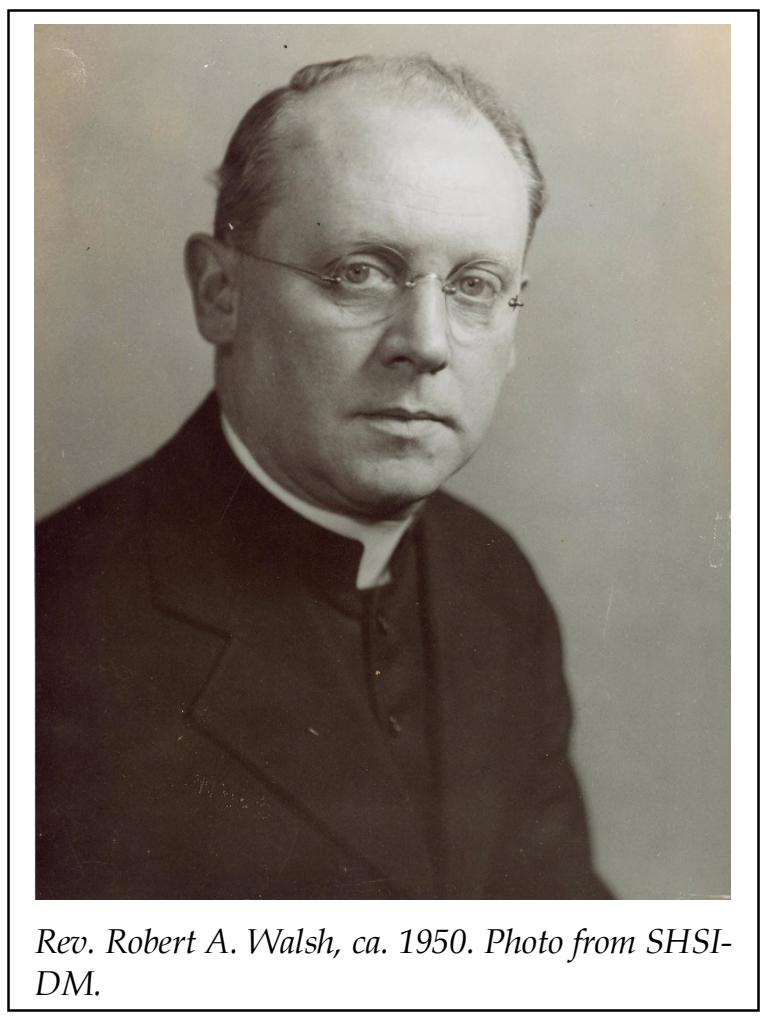

Walsh was appointed to join the trio by Gerald Bergan, who in 1934 had arrived as the new bishop of the Roman Catholic Diocese of Des Moines. He was fond of relating, at least when the rabbi was present, that the first greeters in his new home were Eugene and Irma Mannheimer. ${ }^{16}$ Bergan was bishop of the Diocese of Des Moines until 1948, when he was appointed archbishop of Omaha. With an oratorical style that tended to grandiloquence, he lauded the efforts of the Brotherhood Team:

Inspired with these ideals [of universal brotherhood], and with a love of their fellow man in their hearts, a brave, self-sacrificing little group went forth from Des Moines to preach a gospel of good will: a Rabbi, a Minister, a College Dean [Johnson], a Catholic priest. Like the apostles of old without script [scrip] and meagre of purse, they

16. "Reminiscences," 9:1281. Mannheimer and Bergan lived in the same neighborhood, the well-off south-of-Grand, and Lane lived nearby in the almost as fashionable Waterbury neighborhood. Des Moines City Directory, 1938. 
have traversed the highways and byways of Iowa; stopping at colleges, cities large and hamlets small to tell how civilized Americans should live in peace with one another. 17

In 1942 Walsh was abruptly transferred to Lenox, a tiny parish in southwestern Iowa. The bishop had recruited the Viatorian order to take over teaching at Dowling, and the U.S. entry into World War II was leading to a shortage of priests. ${ }^{18}$ Two months later, after the parish priest at Red Oak left to become a chaplain, Walsh was moved there, even farther from Des Moines. Bergan maintained his support for the brotherhood program and assigned other priests to partner with Mannheimer and Lane, but Walsh would fall from the bishop's good graces (if he had not already done so). Walsh seemed exceptionally ill equipped to be a small-town parish priest; he had grown up in Philadelphia, went to school in Dubuque and at St. Bonaventure, and had spent his career as a priest primarily teaching high school English in Des Moines. Complaints that he failed to pay bills on time reached the bishop's desk, and parishioners made unfavorable comparisons to the previous priest. At one point, after what was seen as excessive requests for reimbursement for gasoline, the bishop forbade Walsh from visiting other priests in Des Moines. Walsh turned his attention to supporting the troops; while visiting troops in Reno, Nevada, he suffered a mental breakdown. ${ }^{19}$

Walsh apparently never worked full time as a priest again, although after his recovery he continued to live in Des Moines

17. "Jews and Christians - Feb. 15, 1938," in folder 1, box 26, subgroup 1, series 9 , Archives of the Archdiocese of Omaha, Omaha; Des Moines Messenger, 2/18/ 1938. For a detailed assessment of Bergan's complex personality, see Stephen Szmrecsanyi, History of the Catholic Church in Northeast Nebraska: Phenomenal Growth from Scannell to Bergan (1891-1969) (Omaha, 1983), 270-75.

18. E-mail correspondence from Steven Avella, 3/18/2015. Avella is working on the first scholarly history of the Des Moines diocese.

19. Walsh personnel file. Perhaps a contributing factor to his breakdown was the extraordinary impact of the war on Red Oak and Montgomery County. The county had the highest per capita casualty rate of any county in the nation. Richard Lingeman, The Noir Forties: The American People from Victory to Cold War (New York, 2012), 22-26; S. M. Senden, Red Oak (Charleston, SC, 2008), 91; Rick Atkinson, An Army at Dawn: The War in North Africa, 1942-1943 (Detroit, 2002), 660-65; Eliot Janeway, "The Midwest's Mood," Part 1, Life, 9/13/1943, p. 11; Christopher Cross, Soldiers of God: True Story of the U. S. Army Chaplains (New York, 1945), 209; Des Moines Diocese History (Des Moines, 1920), 94. 
until his death in 1967. He had one more interreligious responsibility related to the Brotherhood Trio: on September 9, 1952, he served as one of two non-Jewish pallbearers for Rabbi Mannheimer, along with Protestant John Nollen, president of Grinnell College. ${ }^{20}$

IOWA has had a reputation for religious tolerance, not always deserved, but with some basis in fact. ${ }^{21} \mathrm{~A}$ look at county-by-county distribution of denominations in the mid-twentieth century reveals that, by that measure, Iowa was the most religiously diverse state: the Methodist surge due westward from the Chesapeake peninsula dominated the southern third of the state; Scandinavian and German Lutheran communities occupied the northern third, with Dutch Reformed settlements in the northwest; Roman Catholics predominated not just in urban counties but in several rural ones; and counties with Presbyterian, Reorganized Church of the Latter Day Saints (now Community of Christ), and Congregationalist (now United Church of Christ) enclaves also diversify the picture. ${ }^{22}$

The circumstances of settlement also favored tolerance. In The Minds of the West Jon Gjerde argues that in the upper Midwest small groups with ethnic (and religious) affinities typically clustered in rural communities. ${ }^{23}$ In practice, this encouraged positive relations with neighboring clusters of disparate ethnicities and religious affiliations. And, paradoxically, in a new setting with a loosening of hierarchical controls, there were often divisions within ethnic religious groups, opening up the possibility of reconfigurations beyond ethnic boundaries.

20. Walsh personnel file; Des Moines Register, 9/10/1952. For another Catholic tribute to Mannheimer, see folder 32, box 5, William Francis Riley Papers.

21. A spectrum of phrases has been used to describe state policy, public attitudes, and facts on the ground in a modern European-American context: religious toleration, liberty of conscience, disestablishment, tolerance, diversity, and pluralism. I use tolerance because advocates used that term in the 1930s and 1940 s, with the proviso that the Des Moines Brotherhood Trio sought to move "beyond tolerance to respect."

22. Map insert in Frank S. Mead, Handbook of Denominations in the United States, first ed. (New York, 1951); Edwin S. Gaustad and Philip L. Barlow, New Historical Atlas of Religion in America (New York, 2000), 373.

23. Jon Gjerde, The Minds of the West: Ethnocultural Evolution in the Rural Middle West, 1830-1917 (Chapel Hill, NC, 1997), 107-31. 
Iowa's religious diversity depended in part on a variety of dissenting German traditions. Moreover, Iowa's settlement in the 1840s coincided not only with the Transcendentalist moment but also with refugees fleeing repression following the 1848 ferment in Europe. ${ }^{24}$

The Muslim presence in the state, while tiny, was also notable for its longevity and its acceptance by the larger community. Cedar Rapids is home to the Mother Mosque of America (built in 1934); the kinship ties Lebanese and Syrian Christians had already established in the state with Muslim immigrants from the same areas helped smooth the path for early Iowa Muslims including the first Shi' a immigrants to North America. ${ }^{25}$ All these minority influences trended toward tolerance.

Intolerance was not unknown in Iowa, however. Know Nothings gained a foothold in the state in the 1850s, and antiCatholicism was widespread and long lived. ${ }^{26}$ The anti-Catholic American Protective Association was founded in Clinton, Iowa,

24. An example of transplanted Transcendentalism is the pantheist Abner Kneeland. See Stephan Papa, The Last Man Jailed for Blasphemy (Franklin, NC, 1998); and Margaret Atherton Bonney, "Abner Kneeland," in Biographical Dictionary of Iowa, ed. David Hudson, Marvin Bergman, and Loren Horton (Iowa City, 2009), 291-93. On the Forty-Eighter exiles who moved to Davenport and retained freethinker values, see William Roba and Fredrick Anderson, Joined by a River: The Quad Cities (Davenport, 1982), 74. Cedar Rapids Bohemians also had a freethinker streak. For a separate colony of Forty-Eighter exiles, see Béla Vassady, "New Buda: A Colony of Hungarian Forty-Eighters in Iowa," Annals of Iowa 51 (1991), 26-52.

25. Hussien Ahmed Sheronick, "A History of the Cedar Rapids Muslim Community: The Search for an American Islamic Identity" (honors thesis, Coe College, 1988). The naming of the town of Elkader for one of the most prominent nineteenth-century Muslims also suggests an early tolerance. "Iowa Town Named for Muslim Hero Forges World Ties," New York Times, 5/3/2013. While the story of the Cedar Rapids mosque is relatively well known, Fort Dodge, Iowa, was home to perhaps the first Shi'a community in North America. See Diana L. Eck, A New Religious America: How a "Christian Country" Became the World's Most Religiously Diverse Nation (New York, 2001), 244-45; and Cedar Rapids Gazette, 10/11/1959. The Brotherhood Trio spoke in Cedar Rapids, but I have not uncovered a connection between the "Tri-Faith" project and the Muslim community.

26. Robert R. Dykstra, Bright Radical Star: Black Freedom and White Supremacy on the Hawkeye Frontier (Cambridge, MA, 1993), 129-31. See also the special issue of the Annals of Iowa (Winter 1994), with articles by Robert R. Dykstra and Ronald Matthias and a document by William Penn Clarke edited by Tyler Anbinder, all related to the Know Nothing movement in Iowa. 
in 1887 and held its first convention in Belle Plaine. ${ }^{27}$ Anecdotal stories by Edna Ferber, a Jew who endured seven years as a child in Ottumwa from 1890 to 1897,28 and Mary Swander, Iowa poet laureate whose Catholic grandparents were victimized by a $\mathrm{Ku}$ Klux Klan cross-burning in rural Iowa in the 1920s, ${ }^{29}$ suggest reasons that rank-and-file Jews and Catholics would opt for cooperation if Protestants offered it. ${ }^{30}$

The Klan's influence in municipal government in Des Moines, where discrimination in hiring in the police department became a contentious issue, represented a subtler but more insidious anti-Semitism and anti-Catholicism. ${ }^{31}$ The steady drumbeat of reports of increasing anti-Semitism in Germany and elsewhere hit home for Iowa Jews in Des Moines on October 27, 1933, when congregants leaving worship at Tiffereth Israel Synagogue found pro-Nazi flyers on their car windshields. ${ }^{32}$ The WHO and WOC radio broadcasts of the nationally infamous demagogue Father

27. Donald L. Kinzer, An Episode in Anti-Catholicism: The American Protective Association (Seattle, 1964). But a close look at Clinton at the time suggests that political and ethnic rather than religious tensions led to the founding of the APA. See JoAnn Manfra, "Hometown Politics and the American Protective Association, 1887-1890," Annals of Iowa 55 (1996),138-66.

28. Edna Ferber, A Peculiar Treasure (New York, 1938, 31-33). See also Paul Engle, “'Those Damn Jews . . . ,'” American Heritage 30:1 (1978), 72-79; and Louise Rosenfield Noun, Journey to Autonomy: A Memoir (Ames, 1990), 16, 54. Most histories of Iowa Judaism ignore anti-Semitism; an exception is [Oscar Littlefield], I Remember When ... : Personal Recollections and Vignettes of the Sioux City Jewish Community, 1969-1984, comp. Susan Marks Connor (Sioux City, 1985), chap. 8.

29. Mary Swander, Out of This World: A Journey of Healing (New York, 1995), 22022. See also Dorothy Schwieder, " 'A Farmer and the Ku Klux Klan in Northwest Iowa," Annals of Iowa 61 (2002), 287, 298-304; and Robert J. Neymeyer, "In the Full Light of Day: The Ku Klux Klan in 1920s Iowa," Palimpsest 76 (1995), 61-62.

30. Des Moines Protestant ministers were prominent in a Democrats for Hoover movement in 1928. Presbyterian minister James Mordy insisted, however, that the issue they had with Catholic Al Smith was Prohibition, not religion. Des Moines Register, 9/19/1928; Des Moines Tribune, 9/20/1928.

31. Kay Johnson, "The Ku Klux Klan in Iowa: A Study in Intolerance" (M.A. thesis, University of Iowa, 1967), 126, 137-38; Kenneth T. Jackson, The Ku Klux Klan and the City (New York, 1967), 162-63. Alfred L. Severson, professor of sociology at Drake University, reportedly did research on anti-Semitism and job discrimination in Des Moines, following up on his 1934 University of Chicago dissertation on the same topic regarding Chicago, but I have not found anything he published on the subject. Iowa Jewish News, 3/7/1941.

32. Iowa Jewish News, 11/2/1933. 
Charles Coughlin must have made Iowa Jews nervous, and they would have been unsettled as well by the diocesan newspaper, if they had had occasion to read it, with its regular coverage of Coughlin, even though later articles denounced anti-Semitism. ${ }^{33}$

WHILE Jewish and Catholic grievances began to suggest the need for an interreligious detente, making Iowa safe for differences also meant that fractious Protestants would need to learn how to cooperate among themselves. Union services can be traced back as far as the Civil War; county-wide ministerial alliances were common by the 1890s. ${ }^{34}$ When in 1952 the Greater Des Moines Council of Churches formed, the women's representative at the occasion could not resist observing, in congratulating the men who were finally catching up with the women, that Church Women United had a head start of 60 years. ${ }^{35}$ At the turn of the century, when women's ecumenical activity seemed to be taking over the church, the men reacted, nationwide and in Des Moines, with a call for a more masculine church, articulated in the Men and Religion Forward Movement. That impulse, too, was ecumenical. ${ }^{36}$

33. Coughlin made his anti-Semitism explicit only gradually, but the diocesan paper, the Des Moines Messenger, continued to cover him even after his Vatican censure. Aquin, 5/27/1934, 9/2/1934, 11/4/1934; Des Moines Messenger, 1/28/ 1937, 8/19/1937, 12/3/1937, 2/4/1938.

34. William Windsor, Justice and Mercy: A Sermon Preached at a United Service Held in the Methodist Episcopal Church in Davenport, Iowa, on the National Fast Day, June 1st. 1865 [Davenport?, 1865?]; Des Moines Leader, 6/28/1899, 6/29/1899.

35. Des Moines Register, 2/18/1952. Church Women United formed nationally in 1941 as a merger of three national groups, but local groups had existed for decades before that. See Melinda M. Johnson, "Building Bridges: Church Women United and Social Reform Work across the Mid-Twentieth Century" (Ph.D. diss., University of Kentucky, 2015), 1-3. The institutional Protestant churches - or at least the men within it-had had an earlier ecumenical framework in Des Moines, in the Federal Council of Churches, but given that the women's organization had not lapsed in six decades, the Church Women United representative's point seems sound.

36. Bill Douglas, "Iowa Protestantism of 1911," in Trinity United Methodist Church Building Centennial 1911-2011 [Des Moines, 2011], no pagination; Des Moines Register, 6/6/1911; Gail Bederman, “'The Women Have Had Charge Long Enough': The Men and Religion Forward Movement of 1911-1912 and the Masculinization of Middle-Class Protestantism," American Quarterly 41 (1989), 432-65. In her novel The Bonney Family (New York, 1928), 89-92, Ruth Suckow did a hilarious send-up of the movement by putting its premise in the mouths of adolescent males. 
The state of the ecumenical enterprise at the local level in Iowa in the 1920s was limned in Ruth Suckow's novel The Folks, when the protagonists, the Fergusons, who are stalwarts in the struggling Presbyterian Church in Belmond, return from visiting their daughter in California to learn, from their Congregationalist neighbor, that the two churches have merged.

"Well, Fred, I know how you feel, but if you look at it in this way it's pretty nice after all to think that we're all united. For my part," Mr. Viele said boldly, "I'd like to see even the Methodists join in!" He looked triumphantly around the table.... Of course, Mr. Viele added quickly, that didn't include the Catholics. The Methodists were as far as he could go. ${ }^{37}$

In Des Moines, opportunities for making the city safe for religious differences, both within Protestantism and beyond it, were more varied than in an Iowa small town, but the difficulties were evident as different religious entities experimented with joint Thanksgiving services. As Mannheimer found out in factchecking his memoir at the Des Moines Public Library, both interfaith and ecumenical Thanksgiving services preceded his arrival in Des Moines by at least a decade. Thanksgiving, as a unique blend of a secular and religious, but not necessarily Christian, holiday, offered opportunities for interreligious cooperation without compromising doctrinal differences. The tableau of the mythological first Thanksgiving at Plymouth Plantation even offered an interracial and interreligious example. As downtown (white) Protestant churches began holding joint services in Des Moines, Unitarians and Reform Jews also acknowledged their commonalities and began to hold their own joint services. ${ }^{38}$

In 1911 the downtown Protestant and the Unitarian-Reform Jewish Thanksgiving services merged - at least temporarily. But

37. Ruth Suckow, The Folks (1934, reprint, Iowa City, 1992), 694. Suckow, as the daughter of a Congregationalist minister who grew up in many Iowa towns, was an astute observer of Iowa religion. She also had a habit in her novels of renaming Iowa towns with the names of other Iowa towns; "Belmond" is probably Algona.

38. Mannheimer, "Reminiscences," 4:444; Des Moines Leader, 11/26/1896. On the Unitarian-Reform Jew mutual attraction during the 1890s, see Benny Kraut, "The Ambivalent Relations of American Reform Judaism with Unitarianism in the Last Third of the Nineteenth Century," Journal of Ecumenical Studies 23 (1986), 58-68. 
the stretch was apparently too much for many of the Protestants -in 1912 they went back to a Protestant-only service. ${ }^{39}$ Rabbi Mannheimer protested. In an address to his congregation, reprinted in local newspapers, he proclaimed,

If America stands for any one thing more than for all others, it stands for democracy. More than this, its democracy is not the nambypamby, condescending sort which condescends to allow the weak to exist through the gracious favor of the stronger and the minority through the grace of the majority. Everyone is guaranteed his full rights as a man as long as he is worthy of such rights....

And Thanksgiving day becomes the most truly American of all of our American holidays simply because, more than any other, it emphasizes this fundamental unity of the American people as children of one God and equally citizens of the same land. It does not appeal to us as Jewish or Christian, orthodox or liberal, coming from north Europe or south Europe. As men, citizens of this United States, 'God-fearing' men and women as the president calls us in his Thanksgiving proclamation, the day would have us unite to give thanks. ${ }^{40}$

The local press subsequently printed a rebuttal letter from five Protestant ministers from downtown churches: Finis Idleman of the Central Church of Christ (Disciples), J. Edward Kirbye (Plymouth Congregational Church), Howland Hanson (First Baptist Church), A. B. Leamer (St. John's Lutheran Church), and John L. Hillman (First Methodist Church). ${ }^{41}$ Together with the Presbyterians and the Episcopalians (who came later to Protestant

39. Des Moines Register and Leader, 11/30/1911, 12/1/1911, 11/29/1912, 12/2/ 1912, 12/10/1912; Des Moines Capital, 12/1/1911, 11/29/1912, 12/6/1912. Interfaith Thanksgiving services would resume in 1938 under the auspices of the NCCJ Des Moines Round Table, when Bishop Bergan preached at the Thanksgiving morning service held at the Masonic Shrine Temple. Such services would continue until the mid-1940s. Eugene Mannheimer, "History of a Jewish Community as Lived and Recorded in Des Moines, Iowa," [1952], typescript, State Historical Society of Iowa, Des Moines, Book V, 68.

40. Des Moines Register and Leader, 12/2/1912. Looking back with the benefit of hindsight and accumulated wisdom, Mannheimer was ruefully amused by his protest to the newspapers about the exclusion-but in his "Reminiscences" he still argued the point. Mannheimer, "Reminiscences," 4:437.

41. Des Moines Register and Leader, 12/2/1912. In the 1920s Howland Hanson served as director of spiritual life at Des Moines University; he would be the first faculty member dismissed when the fundamentalist Baptist Bible Union 
ecumenism), these denominations constituted the core of mainline Protestantism in Des Moines. ${ }^{22}$ African American Protestant congregations such as Corinthian Baptist Church and St. Paul African Methodist Episcopal Church were also located downtown but were not included.

Even before Stoddard Lane arrived in 1929, Plymouth Congregational Church was a bridge between mainline Protestants and more liberal outliers. In 1918, with the recently concluded war possibly the catalyst, Plymouth found itself sponsoring two Thanksgiving services: the downtown Protestant service in the afternoon, and an evening service open not only to those of any creed, but also, remarkably, to "those of no creed." 43 A devout Plymouth member would have had little time for turkey.

As part of its 75th anniversary celebration in 1932, Plymouth held a Sunday afternoon "Fellowship Service," which featured Rev. George Robinson from an African American congregation, the Corinthian Baptist Church; Father Vitus Stoll, chancellor of the Catholic Des Moines Diocese; Rabbi Mannheimer; and Presbyterian minister James Mordy. ${ }^{4}$ Plymouth was developing the seeds of an interracial and interfaith model.

took over. George S. May, "Des Moines University and Dr. T. T. Shields," Iowa Journal of History 54 (1956), 198, 202.

42. The Episcopalian Iowa diocese at the time leaned toward the Catholic side of its heritage. See Loren N. Horton, The Beautiful Heritage: A History of the Diocese of Iowa, 1853-2003 (Des Moines, 2003), 63. The term mainline has been challenged as anachronistic for this period, but I am convinced that it best describes a force that emphasized denominational institutionalism and ecumenism, rejected the emerging fundamentalist movement, and had continuities with 1960s mainline Protestantism; the terms liberal and modernist are not inclusive enough. See Elesha J. Coffman, The Christian Century and the Rise of the Protestant Mainline (New York, 2013), 4-6, and Gary Dorrien, "The Protestant Mainline Makes a (Literary) Comeback," Religion Dispatches blog, posted 8/5/2013.

43. Des Moines Register, 11/28/1918. There was in a sense a retreat from this position by the late 1930s, when "neo-paganism" was declared the enemy. Of course, that was a code word for Nazism. See "Jews and Christians Vow to Fight Neo-Paganism," Des Moines Register, 2/16/1938. "All religions against no religion" was another slogan of the late 1930s.

44. The Seventy-Fifth Anniversary, 1857-1932, Plymouth Congregational Church (Des Moines, 1932), [6]. The "fraternal addresses" of the congregation's 25th anniversary are reprised in episode VI of the historical pageant and represent a much smaller religious universe of Quaker, Methodist, and Presbyterian representatives. Ibid., [10-11.] 
Making Iowa safe for differences became more urgent for mainline Protestants in the 1920s. As Stoddard Lane was arriving in Des Moines, a much different Protestant entity was making an unceremonious exit. For two years, Des Moines University had served as the de facto headquarters of the Baptist Bible Union, the ultrafundamentalist faction of the Northern Baptist Convention. ${ }^{45}$ For many mainline Protestants, fundamentalists represented both intolerance and irrationality (as well as competition); if the Protestant project was to succeed in its mainline form, tolerance needed to be a central concern. ${ }^{46}$

While cooperation between Protestants and Jews was tentative but increasing, the Catholic-Protestant rivalry was deep-seated, with the quest for dominance in the state preceding statehood. Protestant domination of public schools had provoked the building of a parallel educational system by Catholics in the nineteenth century. ${ }^{47}$ Theologically, pre-Vatican II Catholics faced more obstacles to cooperation; while American Protestants and Jews tended to celebrate individual conscience, Catholicism was anchored to a belief in an indivisible True Church. When Father Walsh lectured at the State University of Iowa, he spoke on the topic of papal infallibility, arguing that a standard of authoritative truth was necessary in an academic world beset by relativism. ${ }^{48}$

Catholic isolation was diffused by World War I, as the war brought an infusion of patriotism to Catholics and a consequent new self-confidence after the war. This seemed particularly evident in Iowa: Dubuque had the only Catholic daily in the country,

45. May, “Des Moines University and Dr. T. T. Shields,” 193-232. On the divergent prejudices of the Baptist Bible Union leaders, see Bill Douglas, "The Culture Wars Get Physical: Des Moines University, 1929," Wapsipinicon Almanac 18, 118-22. (The present-day osteopathic college of the same name is not related.) Northern Baptists and Presbyterians were particularly riven by the fundamentalist controversy. When Mannheimer and Darrow debated, the Register also devoted space to Des Moines University's guest speaker on the subject, who piously felt pity for Darrow. Des Moines Register, 11/15/1928.

46. See Benny Kraut, "A Wary Collaboration: Jews, Catholics, and the Protestant Goodwill Movement," in Between the Times: The Travail of the Protestant Establishment in America, 1900-1960, ed. William R. Hutchison (New York, 1989), 198-202.

47. Jon Gjerde, Catholicism and the Shaping of Nineteenth-Century America, ed. S. Deborah Kang (New York, 2012), 122-23, 168-69.

48. Des Moines Messenger, 11/26/1937. 
the Daily American Tribune, published throughout the 1920s. ${ }^{49}$ The indefatigable Monsignor M. M. Hoffmann founded the Iowa Catholic Historical Society, whose journal chronicled the contributions of Catholics to the state. ${ }^{50}$ But this new assertiveness also opened up possibilities and signaled a willingness to engage in dialogue from a position of relative strength. A new bishop in Des Moines would provide that opening. ${ }^{51}$

THE SOCIAL GOSPEL-ORIENTED Federal Council of Churches (FCC) also took up the cause of making Iowa safe for differences, sending out a national Brotherhood Trio that served as a model for the Des Moines trio. On May 19, 1925, Des Moines clergy involved in the local affiliate of the FCC set up a Committee on Good Will Between Jews and Christians. ${ }^{52}$ National leaders of the FCC felt the need to set up an independent entity to deal with the problem. When Catholics proved responsive to overtures for cooperation, the National Conference of Christians and Jews was established, complete with a nationwide tour by the first Brotherhood Trio: Protestant minister Everett Clinchy, rabbi Morris Lazaron, and Catholic religion professor John Elliott Ross. ${ }^{53}$ Ross, of Charlottesville, Virginia, had taught at the State University of Iowa's School of Religion during the 1929-30 school year. ${ }^{54}$

49. Gallagher, Seed/Harvest, 70, 77.

50. Other midwestern Catholics were also founding state journals. For a description of the Illinois Catholic Historical Review, see Theodore J. Karamanski, "A Catholic History of the Heartland: The Rise and Fall of Mid-America: A Historical Review," Studies in Midwestern History 2 (January 2016), 2-5. Msgr. Hoffmann dropped the last letter of his last name during World War II, much to the frustration of library catalogers. He also wrote a historical romance novel, Young and Fair Is Iowa, in which all the women are fair, all the Catholics are just and pure, and the hero converts to Catholicism in the end.

51. Because priests needed the local bishop's permission to cross diocesan boundaries to speak, it can be assumed that Bishop Bergan obtained the assent of his fellow Iowa bishops to allow Father Walsh to travel the state. On Catholic reluctance to participate fully in the NCCJ project, see Mary Christine Athans, B.V.M., "Courtesy, Confrontation, Cooperation: Jewish-Christian/Catholic Relations in the United States," U.S. Catholic Historian 28 (2010), 113-14.

52. Mannheimer, "Reminiscences," 3:379-B.

53. Pitt, Adventures in Brotherhood, 30-54; Schultz, Tri-Faith America, 35-38.

54. Des Moines Register, 11/17/1933; Lampe, The Story of an Idea, 15; Kraut, "Wary Collaboration," 213-14, 216-19; Iowa Jewish News, 11/16/1933. 
When, on November 16, 1933, the national Brotherhood Trio came to Des Moines, they were "flabberghasted" at the extent of their itinerary on their one-day visit. 55 The well-honed cooperative machinery of the mainline Protestants, their established ties to the Jewish community, and the brand-new interest of the Catholics all contributed to a chock-full day for the three national visitors. At 10:30 a. m., the three spoke to 350 Drake University students on the topic "What Can Young People Do about Racial Prejudice and Intolerance?" At noon they were "warmly received" by 150 men at a Lions Club luncheon. At two they faced 50 clergy members; at 3:30 the three men addressed the Women's Club on the question "To What Extent Do Women Determine Intercultural Attitudes?" From 5:50 to 6:10 they were on WHO Radio, and at 6:30 they gave their evening address at the Younkers Tea Room in downtown Des Moines. At the evening meeting a person with ties to the Ku Klux Klan was reported present, but he drew little sympathy. ${ }^{56}$

The Drake discussion exposed differences among the three speakers, as their individual reports make clear. Lazaron was impatient with mention of theological beliefs as being unproductive. Ross saw a need for historical grounding to explain differences; Clinchy tried to moderate by maintaining that dialogue was the key to understanding. Lazaron also complained that no Catholic colleges had opened their doors to the Brotherhood Trio, a reminder that while Catholics faced prejudice, they also contributed to it. 57

Despite the differences, the appearance at Drake turned out to be particularly fruitful for garnering ongoing local support for the cause. One student dominated the question-and-answer period and challenged Ross's advocacy of tolerance, citing what he had heard about Catholic doctrine and Catholic exclusiveness. In response, a local team promised a follow-up meeting to continue the discussion. That team consisted of friends Stoddard Lane and

55. National Council of Christians and Jews Records, "First Trio Tour-Dictated Notes" folder, box 1, Social Welfare Archives, Libraries of the University of Minnesota, Minneapolis; Des Moines Diocese History [Des Moines, 1970], 94.

56. Ibid; Des Moines Register, 11/16/1933, 11/17/1933; Des Moines Tribune, 11/16/ 1933.

57. NCCJ Records, "First Trio Tour." 
Eugene Mannheimer along with a Catholic priest they met for the first time that day, Rev. Robert Walsh. "All this is an indication of how such movements bring to light characters that have previously been hidden," maintained the national report, foreshadowing the emergence of the Iowa team that adapted the national trio's agenda. ${ }^{8}$

Extant records place Rabbi Mannheimer's first experience as part of a Brotherhood Trio in May 1936, when he substituted for Rabbi Lazaron on the national Brotherhood Trio's second visit to Des Moines. ${ }^{59}$ The Des Moines Tribune's description of the "truth meeting" held at East High School illustrates how the trio operated:

In getting to the truth, they had to stick pins in a lot of rumor bubbles. They joshed and kidded each other - and all to the aim of brotherhood among men....

Father Ahearn explained that he "voted as he darned pleased" and the Pope had nothing to say about it. Besides, the six million Catholic voters in the United States couldn't control an election, he said.

Rabbi Mannheimer explained that only 3 per cent of international capital is controlled by Jews. That the "House of Morgan," in which there are no Jews, controls 32 per cent.

And the Rev. Mr. Clinchy admitted, outright, that there are some things among the Protestants which aren't quite right with the world. Organizations like the Ku Klux Klan, for instance, have set back brotherhood movements. ${ }^{60}$

Such a format proved irresistible to a natural organizer like Willard Johnson, a dean at Drake University and graduate of its divinity school, who was hired in 1936 to a part-time position with the Des Moines Round Table, the local affiliate of the National Council of Christians and Jews. In 1938 he would become full-time regional director of the NCCJ. ${ }^{61}$ As impresario for the trio, Johnson brought an organizational intensity and enthusiasm

58. Ibid.

59. Correspondence in the NCCJ Records between Mannheimer and Johnson in 1950 suggests that the early records of the Des Moines Trio were tossed out by Johnson's successor as regional director of the NCCJ in St. Louis. Mannheimer's "Reminiscences" also frequently suggest that his records are probably incomplete. 60. Mannheimer, "Reminiscences," 3:387; Des Moines Tribune, 5/25/1936.

61. Mannheimer, "Reminiscences," 3:386. On Johnson's subsequent career as a national and international leader in interfaith endeavors, see NCCJ Records, box 9. 
that would ensure that the Iowa trio's oratorical, preaching, and narrative skills would reach receptive audiences across the state. He was also the only native midwesterner in the group and had the most experience with small-town Iowa life.

MANNHEIMER, WALSH, AND LANE soon replicated and improved on the national format locally, improvising an Iowa version of the national Brotherhood Trio's themes. Their first appearance was on WHO Radio on October 15, 1936, where they argued for moving "Beyond Tolerance to Respect." The first listing in Mannheimer's "Reminiscences" of the trio on the road was in response to an episode of anti-Semitism in the Quad Cities, on April 28, 1938. However, Bishop Bergan's February 1938 speech makes clear that they had been traveling as a team for a considerable time before that, a fact confirmed by the Davenport Democrat and Leader, which reported that their 1938 visit was a reprise of their visit the previous year. ${ }^{62}$

While apparently incomplete, Mannheimer's itinerary in his reminiscences lists trio visits to 44 different towns in Iowa (some more than once), trips to several other midwestern states, and 33 appearances in Des Moines - only 8 of those in religious settings. Records in the NCCJ archives claim that the Des Moines Brotherhood Trio logged over 11,000 miles on the road during their campaign. ${ }^{63}$ The attendance listed is also impressive: 1,100 in Ottumwa, 1,000 in Marshalltown, 750 in Albia, and 350 in Kimballtown, a Danish Lutheran town with a population of 378. On their second visit to Davenport, a local newspaper reported that 1,500 attended. This being Iowa, their lore could not be complete without tales of "further adventures on the road," struggling their way back to Des Moines from Marshalltown and Boone during blizzards. ${ }^{64}$

62. "Jews and Christians-Feb. 15, 1938," in folder 1, box 26, subgroup 1, series 9, Archives of the Archdiocese of Omaha, Omaha; Davenport Democrat and Leader, 4/14/1938, 4/30/1938. A local Mason City trio spoke there in 1935; their tone was much more earnest. Iowa Jewish News, 2/22/1935, 3/1/1935.

63. Pitt, Adventures in Brotherhood, 59. Close to half of the Trio's Iowa appearances were in Des Moines, though they were mostly unreported by the local press. 64. Mannheimer, "Reminiscences, 4:425-28, 3:401, 1:106-7, 3:405-6; Davenport Democrat and Leader, 4/30/1938. 


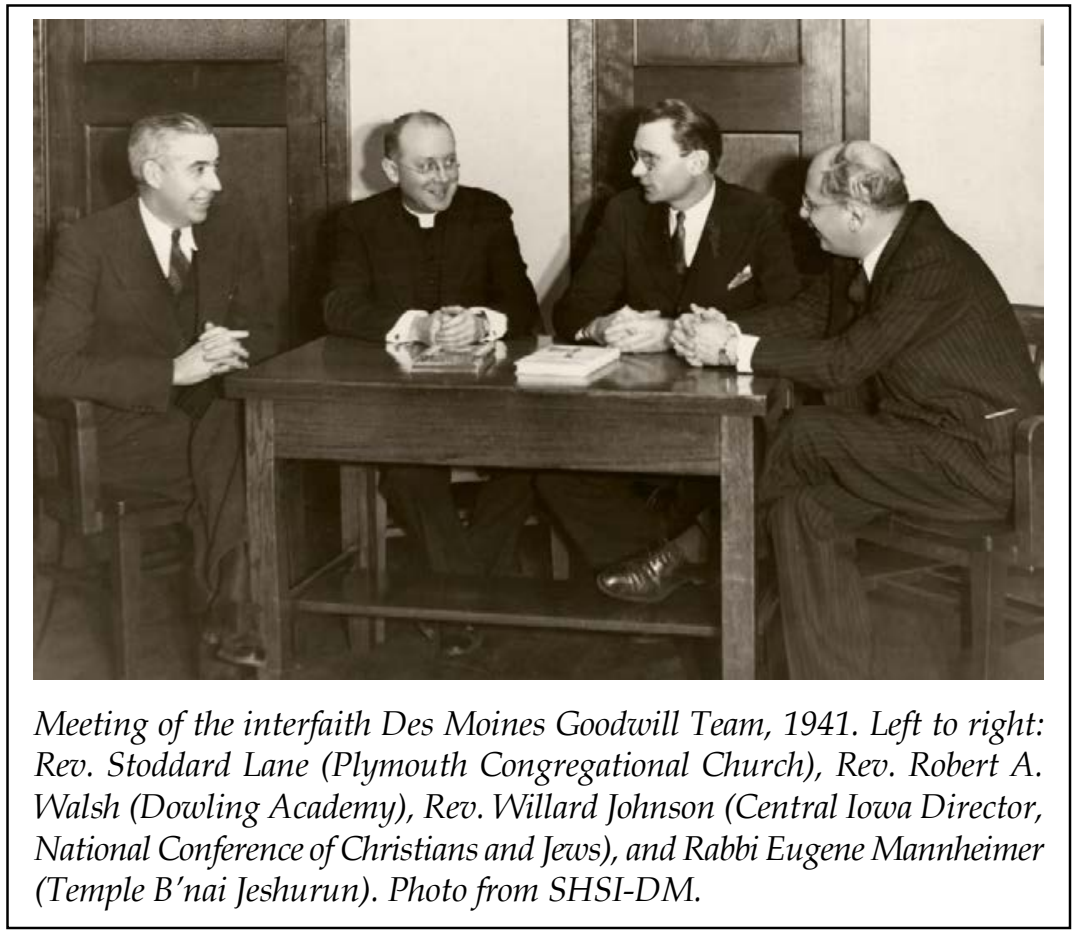

James Pitt's description of the trio's performance, based on NCCJ files that replicate Mannheimer's account, is worth quoting at length:

The standard opening: Johnson appeared on stage, looked at his watch, remarked that the men were late again - as usual. When the three came in, one by one, quite apologetic, they seated themselves around Johnson's desk, with Father Walsh inevitably seated between Lane and Mannheimer. Walsh would say: "I guess I'm between the devil and the deep blue sea.". . .

If the next program was to be in, say, Oskaloosa, one would ask, "Just where is that place?" "Oh, that's that little suburb of Ottumwa's." "They don't have any prejudices in Oskaloosa, do they?" "No, no prejudice there-except against Ottumwa and the Ottumwa football team" - or whatever team had just beaten the Oskaloosans.

Here, the topic usually turned to a discussion of what prejudice is. ...

The discussion would [soon] turn to a discussion about whether priests kept their parishioners "right under their thumb," 
and Father Walsh had another story for the occasion about the nonCatholic who attended a Catholic service. He hurried home to tell his wife that at one point the priest had taken his stand, looked the congregation right in the eye, and said: "Dominick, go frisk 'em." And a group of men rushed out to do just that. ...

Here, Mannheimer would suggest that the group should visit the synagogue, "because we never take up collection at services." When another would ask how the Temple got its money, he would say, "Oh we frisk 'em before they come."

... Throughout the fun-filled, seemingly hit-or-miss program, however, ran very basic purposes: 1) To make clear that there was absolutely nothing concerning intergroup problems that the team would not readily discuss freely without arguing doctrine or dogma. 2) To throw light on common, prevailing or historic misconceptions and prejudices entertained by any majority or minority group. 3) To emphasize that there are fundamental differences in beliefs, theologies, institutions and religious practices. 4) To emphasize as strongly as possible that members of the three faiths had things in common as American citizens, even though doctrinal differences remained.

5) To leave no doubt or misunderstanding about the aims of the program and the purpose of the NCCJ. ${ }^{65}$

Local news accounts, unanimously positive, mostly stressed the audience's receptivity to the trio's message. ${ }^{66}$ Often, the invitation and the turnout were written up as reflecting well on the town: the Story City Herald was particularly proud of the townspeople's reaction to the trio. But such stories played into the Goodwill Team's message that neighborly Iowans were beyond prejudice (or should be).

65. Pitt, Adventures in Brotherhood, 59-61; see also NCCJ Records and Mannheimer, "Reminiscences," vol. 3.

66. Local news accounts I have found (not otherwise cited) include Indianola Tribune, 2/16/1938; Oskaloosa Herald, 3/2/1938; Jasper County Record, 3/3/1938; Mason City Globe-Gazette, 3/14/1938, 3/16/1938; Grinnell Scarlet and Black, 10/5/1938, 10/26/1938; Osceola Herald, 11/15/1938; Albia Union-Republican, 1/26/1939, 2/2/1939; Boone Republican, 2/1/1939; Mount Vernon Hawkeye Record and Lisbon Herald, 4/27/1939, 11/14/1940; Storm Lake Pilot-Tribune, 1/11/ 1940, 1/18/1940; Lake View Resort, 1/18/1940; Spencer Reporter, 1/18/1940; Audubon Advocate-Republican, 2/29/1940, 3/7/1940; Des Moines Messenger, 4/5/ 1940; Osceola Sentinel, 4/29/1940; Chariton Herald Patriot, 5/2/1940, 5/9/1940; Stuart Herald, 10/17/1940, 10/24/1940; Story City Herald, 2/5/1941; Creston News Advertiser, 2/14/1941, 2/15/1941; Iowa Jewish News, 2/21/1941; Pella Chronicle, 4/24/1941; Bedford Times Press, 5/15/1941; Red Oak Express, 4/29/1943. 
Later, as World War II increasingly preoccupied Americans, international reasons for tolerance became more prominent. Typical of an early 1940s event (except for the absence on this occasion of Stoddard Lane) is this prediction by the Pella Chronicle, undoubtedly relying on the press release sent out from Des Moines by Willard Johnson:

The most interesting Open Forum of the season will be heard at the high school auditorium next Monday evening, when Rabbi Eugene Mannheimer, Father Robert A. Walsh and Reverend Willard Johnson will discuss informally the Relation of Religion to Democracy and the Need for Debunking Prejudices About All Groups. The program ... has interested thousands of people throughout Iowa. ... The principles underlying their work are: respecting the sincere convictions of others and co-operation without watering down belief. They say: "The enemies of democracy use as their chief weapons prejudice and intolerance. To save democracy, American groups must mutually respect each other." 67

By the 1950s it became fashionable, even within the NCCJ, to criticize trio teams for their emotionalism. They were also criticized for their failure to address racial intolerance, a concern the Des Moines Round Table did sometimes address. ${ }^{68}$ More trenchantly, there was the absence of a critique of economic inequality; and the very name Brotherhood Trio suggests an exclusion that would not be acceptable today, especially given women's presence in leadership in two of the three traditions.

Following the lead of the national NCCJ, by the early 1940s the enemy became not so much the irrational prejudices of American religious traditions as it was the paganism and atheism of totalitarian societies abroad. That retrenchment to a Judeo-Christian core, backing away from "Making America Safe for Differences," positioned religious tolerance as an ally in the looming war against fascist states but opened a potential new argument for religious intolerance against those outside the consensus and would work well, after the war, as an argument in favor of the Cold War, which was accompanied by some intolerance.

67. Pella Chronicle, 4/17/1941.

68. See, for example, Mannheimer, "Reminiscences," 3:393. The Des Moines Round Table attempted scientific surveys to gauge public opinion. Ibid., 3:355. 
The fissures among the Iowa Goodwill Team were subtle but, in retrospect, significant. They were not, as was the case with the first national trio, along theological or denominational lines; in fact, the two Protestants represented the polarities. Willard Johnson, with an organizer's eye toward achieving a workable majority, was always seeking the consensus of American civil religion to anoint religious tolerance; Stoddard Lane, the stalwart pacifist, did not see American nationalism as a transcendent good and was unwilling to accede to such expedience as a reason to accept diversity. He argued for shared humanity rather than shared citizenship. Mannheimer leaned toward Lane's side of the equation, Walsh toward Johnson's.

IN A SPEECH to a banquet of the Des Moines Round Table of the National Conference of Christians and Jews in 1954, Gerald Bergan, by then the archbishop of Omaha, assessed the efforts of the past decade. He asserted that the Des Moines Brotherhood Trio had fundamentally changed the culture of Iowa regarding religious tolerance. ${ }^{69}$ We may expect faith statements from bishops and other religious leaders; arguably, religious leaders do not acknowledge social conversion often enough. But historians must deal not with the evidence of things unseen, but with fruits of the spirit that are tangible and have a very long shelf life. Even within those chastened parameters, it is clear that the Des Moines Brotherhood Trio assiduously advocated at the grassroots level for a new level of religious tolerance that was consonant with predominant national trends and favored progressive ideals in an embattled world context. It helped that Iowans generally wanted to be good neighbors, accustomed as they were to dealing with religious diversity.

Jane Addams insisted that "the good we secure for ourselves is precarious and uncertain until it is secured for all of us and incorporated into our common life."70 Making Iowa safe for differences was, and is, an unfinished project. As Rabbi Mannheimer reviewed his youthful protest at the 1912 exclusion of Jews and

69. Schultz, Tri-Faith America, 40.

70. Quoted in Eboo Patel, Sacred Ground: Pluralism, Prejudice, and the Promise of America (Boston, 2012), vii. 
Unitarians from union Thanksgiving services, despite the trifaith entente that existed at mid-century, he still felt the pressures of other historical events when he mused, "I certainly was a bit over-optimistic back in 1912 . . . in maintaining that we could 'look forward to the coming of the time, at no greatly distant future, when the spirit of brotherhood, growing out of a faith in a universal God, shall triumph' on earth. Now, in August 1950, the millennium does appear to be considerably further distant than it appeared to many of us to be in 1912." 71 That receding vision continues to be elusive, but still suggests that another world is possible.

71. Mannheimer, “Reminiscences,” 4:438. 